\title{
Determination of free and bounded phenolic acids in the rhizomes and herb of Sanguisorba officinalis L.
}

\author{
Anna Biernasiuk ${ }^{1}$, Michal Wozniak ${ }^{2 *}$, Anna Bogucka-Kocka ${ }^{2}$ \\ ${ }^{1}$ Department of Pharmaceutical Microbiology, Medical University of Lublin, Poland, Chodzki 1, 20-093 Lublin, Poland \\ ${ }^{2}$ Department of Pharmaceutical Botany, Medical University of Lublin, Poland, Chodzki 1, 20-093 Lublin, Poland
}

\begin{tabular}{|c|c|}
\hline ARTICLE INFO & ABSTRACT \\
\hline $\begin{array}{l}\text { Received } 14 \text { September } 2015 \\
\text { Accepted } 24 \text { September } 2015\end{array}$ & $\begin{array}{l}\text { An analysis of the fractions of free acids and phenolic acids liberated by way of hydrolysis } \\
\text { in the rhizomes and herbaceous tissues of Sanguisorba officinalis L. was conducted }\end{array}$ \\
\hline $\begin{array}{l}\text { Keywords: } \\
\text { Sanguisorba officinalis L., } \\
\text { phenolic acids, } \\
\text { 2D-thin layer chromatography. }\end{array}$ & $\begin{array}{l}\text { through utilizing the } 2 \mathrm{D} \text {-TLC method. Fifteen phenolic acids were identified. Our work } \\
\text { showed that ellagic, protocatechuic, gentisic, p-hydroxybenzoic, syringic, vannilic and } \\
\text { ferulic acids were common in all tested fractions, and gallic and protocatechuic acids } \\
\text { were dominant in fractions obtained from the rhizomes, while caffeic, p-coumaric, } \\
\text { syringic, vannilic and ferulic acids were abundant in the herbaceous tissues. However, } \\
\alpha \text { and } \beta \text { - resorcylic acids were detected only in rhizome phenolic acid fractions liberated } \\
\text { from their conjunction with sugars and alcohols. Furthermore, chlorogenic acid was } \\
\text { present only in a free form in the herbaceous tissues, while p-hydroxyphenylacetic acid } \\
\text { was liberated from conjunction from a herbaceous extract. }\end{array}$ \\
\hline
\end{tabular}

\section{INTRODUCTION}

Sanguisorba officinalis L. (Rosaceae) is a perennial plant widely distributed in Asia, and has been used in traditional Chinese medicine as a haemostatic, astringent and anti-inflammatory agent, in the treatment of inflammatory and metabolic diseases such as diarrhoea, chronic intestinal infections, duodenal ulcers and internal haemorrhage $[4,8]$.

It has been demonstrated previously that Sanguisorbae radix extracts possess strong free radical-scavenging activity in-vitro and in-vivo. Protection activity against renal disease, which is closely associated with excessive generation of reactive oxygen species, as well as suppression of lipid peroxidation, were noticed. This suggests the active compounds may be effective agents for ameliorating the pathological conditions related to excessive generation of free radicals and oxidant damage [17]. Moreover, standardized water extracts from its rhizomes are rich in catechin and epicatechin, hence, have neuroprotective effects against impairments caused by 6-hydroxydopamine, which leads to the generation of reactive oxygen species (ROS) in human neuroblastoma cell lines. The mechanism of protection is connected with decreasing ROS overproduction

\footnotetext{
* Corresponding author

e-mail:micwoz1@wp.pl

tel.: +48 814487060 ; fax: +48814487060
}

and with regulating the Bcl-2 family protein, as well as with inhibiting cyt $\mathrm{C}$ release [9]. Gallic acid seems to be the leading compound responsible for the neuroprotective properties of Sanguisorbae radix extracts against amyloid $\beta$-protein induced toxicity in cultured rat cortical neurons [2]. Tannins also significantly inhibit the formation of both nitric oxide (NO) and inducible NO synthase [6]. Additionally, methanolic extracts from Sanguisorbae radix act as anti-inflammatory agents that decrease the production of TNF- $\alpha$ and IFN- $\gamma$, resulting in reductions of skin lesions and histopathological changes in inflamed skin tissues [6].

The whole plant family is rich in phenolic compounds, mostly phenolic acids, tannins and flavonoids [18]. Previous experiments showed also the presence of a series of triterpenoids $[4,15]$, however, the high radical scavenging activity (a DPPH scavenging capacity that is higher than $90 \%$,) is strongly connected with the high level of total phenolic content. This has been calculated as being 1.96\% - higher than that of black bean $(1.82 \%)$ or red bean $(1.10 \%)[1,12]$.

Even today, the full profile of phenolic acids in Sanguisorbae radix is not known. As mostly the roots of this plant family were examined in previous work, the aim of our study was to identify the phenolic acids in both the rhizomes and the herbaceous tissues of Sanguisorba officinalis L. by way of simple chromatographic methods. 


\section{MATERIAL AND METHODS}

Plant material. The rhizomes and herbaceous tissues of the tested plant were collected from a natural site in the Lublin district (Eastern Poland). The herbaceous tissue was collected in June at the blooming stage, while the rhizomes were gathered at the beginning of September. All materials were cleaned and inspected to remove damaged and diseased parts. The plant tissues were dried in normal conditions and then pulverized and sieved. In our work, $100 \mathrm{~g}$ of rhizomes and $100 \mathrm{~g}$ of herbaceous tissue were utilized. Note: samples of the gathered plant material are deposited in the Department of Pharmaceutical Botany, Medical University of Lublin.

Extraction and isolation. The air-dried rhizomes, as well as the herbaceous tissues of S. officinalis (100 g each) were extracted exhaustively through the use of a Soxhlet apparatus, employing first, petroleum ether $\left(60 \mathrm{~h}, 45-60^{\circ} \mathrm{C}\right)$ and then secondly, exposing this three times to boiling $80 \%$ methanol (1000 $\mathrm{ml}$ each), in a hot water bath under the reflux. The aqueous-methanol extracts were concentrated under reduced pressure, and the viscous concentrates were eluted with hot water portions. After $24 \mathrm{~h}$, the aqueous fractions were filtered.

Free phenolic acids fractions (A) were obtained according to the process utilized by Ibrahim and Towers [5] and Krzaczek [7], by extraction with diethyl ether and sodium bicarbonate. The water fraction was also subjected to acid and alkaline hydrolysis in order to liberate the acids presented as glycosides and esters, respectively. The subsequent hydrolysis was performed according to the process outlined by Schmidtlein and Herrmann [11]. Therein, the fractions of phenolic acids liberated from their conjunction with sugars and alcohols were obtained (B).

Thin-layer chromatography. Two-dimensional chromatography was performed on $100 \times 100 \times 0.1 \mathrm{~mm}$ plastic cellulose plates (E. Merck, Darmstadt, Germany), according to the method described by Smolarz and Waksmundzka-Hajnos [13]. DS horizontal chambers were used in this study. The plates were developed in two directions: in the first direction, the mobile phase was composed of benzene-methanol-acetic acid-acetonitrile (80:10:5:5 v/v), while sodium formate-formic acid-water $(10: 1: 200 \mathrm{w} / \mathrm{v} / \mathrm{v})$ was applied in the second direction.

Before development in the first direction, in order to avoid demixing, the plates were conditioned in the chambers for 5 $\mathrm{min}$ in the vaporous layer above benzene-methanol-acetic acid $(94: 1: 5 \mathrm{v} / \mathrm{v})$. For the detection of the $\alpha, \beta$ and g-resorcilic acids, benzene-buthyl acetate-acetic acid-acetonitrile (70:20:5:5 v/v) (first direction), and dioxin-toluene-heptanacetic acid (40:30:30:1 v/v) (second direction) were used.

After development in the first direction, the eluent was completely evaporated by drying in air. After this, the chromatograms were observed in UV light $(\lambda=366 \mathrm{~nm})$ before and after treatment with ammonia vapour. Visualisation was performed by spraying with a $2 \%$ aqueous solution of ferric chloride $\left(\mathrm{FeCl}_{3}\right)$ and diazotized sulfanilic acid (dSA) in $20 \%$ sodium carbonate solution, as well as diazotized p-nitroaniline (pNA) [13,14].
The contained phenolic acids were identified on the basis of comparison of the colors (before and after derivatization), and by comparison of the $\mathrm{R}_{\mathrm{F}}$ values of the analyzed compounds, with those of authentic standards.

\section{RESULTS AND DISCUSSION}

In our work, we analyzed fractions of free phenolic acids and those liberated from their conjunction with sugars and alcohols after acid and alkaline hydrolysis, from an aqueousmethanol extract of both rhizome and herbaceous tissues of S. officinalis L. The simple 2D-TLC method was employed and found to be an efficient tool for the separation of secondary plant metabolites from such a complex mixture as a plant extract [13]. Fifteen compounds were identified in total: ellagic, chlorogenic, gallic, protocatechuic, caffeic $(E+$ $Z$ ), gentisic, $\alpha$ - and $\beta$-resorcylic, p-hydroxyphenylacetic, p-hydroxybenzoic, p-coumaric $(E+Z)$, syringic, vannilic, sinapic $(E+Z)$, ferulic $(E+Z)$ (Table 1 and 2$)$.

Ellagic, protocatechuic, gentisic, p-hydroxybenzoic, syringic, vannilic and ferulic acids were found to be common in all tested fractions. Gallic and protocatechuic acids were dominant in fractions obtained from the rhizomes, while caffeic, p-coumaric, syringic, vannilic and ferulic acids were abundant in the herbaceous tissues. However, $\alpha$ and $\beta$ - resorcylic acids were detected only in the fraction of phenolic acids liberated from their conjunction with sugars and alcohols (B) from the rhizomes. In addition, chlorogenic acid was present only in a free form in the herbaceous tissues, while p-hydroxyphenylacetic acid was liberated from conjunction from a herbaceous extract (Table 1). Our investigation confirm the presence of chlorogenic, ellagic, gallic, caffeic and ferulic acids, while the other acids were identified for the first time. According to Pelc et al. [10], who examined 10 populations of $S$. officinalis growing wild

Table 1. The occurrence of phenolic acids in Sanguisorba officinalis $\mathrm{L}$.

\begin{tabular}{|c|c|c|c|c|c|}
\hline \multirow{2}{*}{ No. } & \multirow{2}{*}{ Phenolic acids } & \multicolumn{2}{|c|}{ Rhizomes } & \multicolumn{2}{|c|}{ Herb } \\
\hline & & A & B & A & B \\
\hline 1. & ellagic & + & - & + & - \\
\hline 2. & chlorogenic & - & - & + & - \\
\hline 3. & gallic & + & + & - & + \\
\hline 4. & protocatechuic & + & + & + & + \\
\hline 5. & caffeic $(E+Z)$ & - & + & + & + \\
\hline 6. & gentisic & + & + & + & + \\
\hline 7. & $\begin{array}{l}\text { p-hydroxy- } \\
\text { phenylacetic }\end{array}$ & - & - & - & + \\
\hline 8. & p-hydroxybenzoic & + & + & + & + \\
\hline 9. & $\mathrm{p}$-coumaric $(E+Z)$ & - & + & + & + \\
\hline 10. & syringic & + & + & + & + \\
\hline 11. & vanillic & + & + & + & + \\
\hline 12. & sinapic $(E+Z)$ & - & + & + & + \\
\hline 13. & ferulic $(E+Z)$ & + & + & + & + \\
\hline 14. & a - resorcylic & - & + & - & - \\
\hline 15. & $\beta$ - resorcylic & - & + & - & - \\
\hline
\end{tabular}


in Poland, the underground organs are rich in ellagic and gallic acids. In the herbaceous tissues, Pelc et al. identified five phenolic acids, namely: chlorogenic, ellagic, gallic, caffeic and rosmarinic acid.

Many other studies have suggested the strong antioxidant activity of the phenolic compounds known to be contained in S. officinalis (the catechins, quercetin and kaempferol), and their neuroprotective effect [8]. Our research, in turn, has confirmed the existence of a diversity of phenolic acids in the rhizomes and herbaceous tissues of $S$. officinalis. These are well-known for strong antioxidant activity, and they and the plant itself, as well as the techniques we employed, are worthy of further pharmacological research.

Table 2. Color spot reactions of identified phenolic acids separated by TLC before and after derivatisation

\begin{tabular}{|c|c|c|c|c|c|c|}
\hline $\mathrm{Nr}$ & Phenolic acids & $\begin{array}{c}\text { UV } \\
a=366 \mathrm{~nm}\end{array}$ & $\mathrm{NH}_{3} / \mathrm{UV}$ & dSA & dNA & $\mathrm{FeCl}_{3}$ \\
\hline 1. & ellagic & - & - & $\begin{array}{l}\text { light } \\
\text { brown }\end{array}$ & $\begin{array}{c}\text { brownish- } \\
\text { red }\end{array}$ & brown \\
\hline 2. & chlorogenic & blue & $\begin{array}{c}\text { yellowish- } \\
\text { green }\end{array}$ & $\begin{array}{l}\text { light } \\
\text { brown }\end{array}$ & lemon & $\begin{array}{l}\text { grey- } \\
\text { green }\end{array}$ \\
\hline 3. & gallic & violet & violet & $\begin{array}{l}\text { light } \\
\text { brown }\end{array}$ & $\begin{array}{c}\begin{array}{c}\text { greenish- } \\
\text { red }\end{array} \\
\end{array}$ & grey \\
\hline 4. & protocatechuic & violet & violet & brown & \begin{tabular}{|c|}
$\begin{array}{c}\text { reddish- } \\
\text { brow }\end{array}$ \\
\end{tabular} & $\begin{array}{c}\begin{array}{c}\text { brownish- } \\
\text { blue }\end{array} \\
\end{array}$ \\
\hline 5. & caffeic $(E+Z)$ & blue & blue & brown & brown & $\begin{array}{c}\text { brownish- } \\
\text { green }\end{array}$ \\
\hline 6. & gentisic & blue & yellow & grey & $\begin{array}{l}\text { grey- } \\
\text { green }\end{array}$ & navy blue \\
\hline 7. & $\begin{array}{l}\text { p-hydroxy- } \\
\text { phenylacetic }\end{array}$ & - & - & pink-blue & violet & - \\
\hline 8. & p-hydroxybenzoic & - & - & yellow & red & - \\
\hline 9. & p-coumaric $(E+Z)$ & light blue & blue & red & \begin{tabular}{|c}
$\begin{array}{c}\text { brownish- } \\
\text { blue }\end{array}$ \\
\end{tabular} & - \\
\hline 10. & syringic & - & - & dark red & blue & - \\
\hline 11. & vanillic & - & - & orange & violet & brown \\
\hline 12. & sinapic $(E+Z)$ & blue & $\begin{array}{l}\text { bluish- } \\
\text { green }\end{array}$ & violet-red & $\begin{array}{c}\text { brownish- } \\
\text { blue }\end{array}$ & brown \\
\hline 13. & ferulic $(E+Z)$ & blue & blue & violet & blue & $\begin{array}{c}\text { light } \\
\text { orange }\end{array}$ \\
\hline 14. & a - resorcylic & - & - & $\begin{array}{l}\text { yellow- } \\
\text { brown }\end{array}$ & $\begin{array}{c}\text { light } \\
\text { brown }\end{array}$ & light blue \\
\hline 15. & $\beta$ - resorcylic & - & violet & $\begin{array}{l}\text { yellow- } \\
\text { brown }\end{array}$ & \begin{tabular}{|c} 
brownish- \\
red
\end{tabular} & $\begin{array}{c}\text { brownish- } \\
\text { violet }\end{array}$ \\
\hline
\end{tabular}

Explanation:

(dSA) - diazotized sulfanilic acid; (pNA) - diazotized p-nitroaniline; $\left(\mathrm{FeCl}_{3}\right)$ - ferric chloride

\section{REFERENCES}

1. Amarowicz R, Pegg RB.: Legumes as a source of natural antioxidants. Eur. J. Lipid Sci. Tech., 110, 865, 2008.

2. Ban J.Y. et al.: Neuroprotective properties of gallic acid from Sanguisorbae Radix on amyloid $\beta$ Protein (25-35)-induced toxicity in cultured rat cortical neurons. Biol. Pharm. Bull., 31, 149, 2008.

3. Cieśla Ł.M. et al.: Thin-layer chromatography coupled with biological detection to screen natural mixtures for potential drug leads. Phytochem. Lett., 11, 445, 2015.

4. Hu J. et al.: Nordammarane triterpenoids from Sanguisorba officinalis. Helvet. Chim. Acta, 98, 273, 2015.

5. Ibrahim R.K., Towers G.H.: Identification by chromatography of plant phenolic acids. Arch. Biochem. Biophys., 87, 125, 1960.

6. Jo S.et al.: Anti-inflammatory effects of Sanguisorbae Radix on contact dermatitis induced by dinitrofluorobenzene in mice. Chin. J. Int. Med., in press (2015).

7. Krzaczek T.: Fenolokwasy w różnych surowcach garbnikowych z rodziny Rosaceae. Farm. Pol., 40, 475, 1984.

8. Nguyen T.T.H. et al.: Neuroprotective effect of Sanguisorbae radix against oxidative stress-induced brain damage: In vitro and in vivo. Biol. Pharm. Bull., 31, 2028, 2008.

9. Oh H. et al.: Sanguisorbae radix protects against 6-hydroxydopamine-induced neurotoxicity by regulating NADPH oxidase and NF-E2-related factor-2/heme oxygenase-1 expressions. Phytother. Res., 27, 1012, 2013.

10. Pelc M. et al.: Chemical variability of great burnet (Sanguisorba officinalis L.) growing wild in Poland. Acta Hort., 925, 97, 2011.

11. Schmidtlein H., Herrmann K.: Quantitative analysis for phenolic acids by thin layer chromatography. J. Chromatogr., 115, 123, 1975.

12. Shun Wan $\mathrm{C}$ et al.: Antioxidant activity of Chinese medicinal herbs. Pharm. Biol., 46, 587, 2008.

13. Smolarz H.D., Waksmundzka-Hajnos M.: Two-dimensional TLC of phenolic acids on cellulose J. Planar Chromatogr., 6, 278, 1993.

14. Sokołowska-Krzaczek A., Skalicka-Woźniak K., Czubkowska A.: Variation of phenolic acids from herb and roots of Salsola kali L. Acta Soc. Bot. Polon., 78, 197, 2009.

15. Sun L.L. et al.: Chemical constituents from charred Sanguisorbae Radix. Chin. Trad. Herb. Drugs, 44, 646, 2013.

16. Yokozawa T. et al.: A study on the nitric oxide production-suppressing activity of Sanguisorbae Radix components. Biol. Pharm. Bull., 23, 717, 2000.

17. Yokozawa T., Chen, P.C. Evidence suggesting a nitric oxide-scavenging activity for traditional crude drugs, and action mechanisms of Sanguisorbae Radix against oxidative stress and aging. J. Am. Aging Assoc., 24, 19, 2001.

18. Zhang S. et al.: Isolation and identification of the phenolic compounds from the roots of Sanguisorba officinalis L. and their antioxidant activities. Molecules, 17, 13917, 2012. 